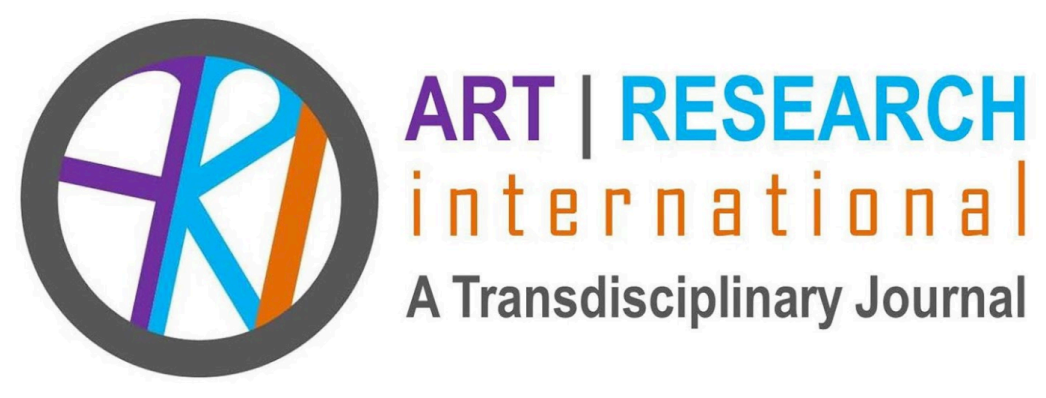

\title{
THE DEMON OF HOPE: AN ARTS-BASED INFUSED MEDITATION ON RACE, DISABILITY, AND THE RESEARCHER'S COMPLICITY WITH INJUSTICE
}

\author{
Gene Fellner \\ City University of New York, \\ College of Staten Island \\ genefellner@gmail.com
}

\begin{abstract}
Gene Fellner: I received my PhD in Urban Education in 2012 after having spent the previous 40 years as an artist and political activist. I was a staff member of the Attica Brothers Legal Defense in the '70s and went to Nicaragua as a brigadista in 1985 where I painted murals with Sandinista artists. For the past 12 years, I have worked in Newark, $\mathrm{NJ}$, in its most underserved schools, with students and teachers. I am an Assistant Professor of Education at the City University of New York.
\end{abstract}

Abstract: My ethical stance demands that my research mutually benefit all research participants and that it should serve to reverse systemic policies of anti-blackness that permeate the educational system in the United States. Through publications and similar academic activities, however, my research advances my own career, but it is doubtful that it significantly advances the trajectories of the students with whom I work. Indeed, it could be argued that this imbalance in benefits advances the very system of white dominance that I claim to contest. In this arts-based, auto-ethnographic study, I document how, through the creation of pastel drawings and digital collage making, I seek to make sense of my compromised role as a white researcher in communities of color. I focus on my recent research with an 18-year-old African-American woman who was diagnosed with ADHD in the $5^{\text {th }}$ grade. 
Keywords: arts-based research; special education; disability studies; race; research ethics; whiteness 


\section{The Catalyst for this Study}

The compromised role of the white researcher who works with students in communities of color unsettled me again when Alysha (pseudonym), an 18-year-old AfricanAmerican student in a transfer school that serves over-aged and under-credited students, withdrew permission to use her image and name from an article I was writing about her. For two years we had worked closely together, and I was certain the work we were doing was benefiting her while simultaneously serving my research agenda. My own ethical stance on research demands this mutual benefit. But now, with Alysha's sudden choice of anonymity, I wondered if I was the only person to benefit from the research we had undertaken together. This posed an ethical quandary in which race played a central role.

Alysha's educational trajectory aligned in crucial ways with that of many students with whom I have worked. She had failed almost all her courses

"Though Alysha remains an important figure in this article, it is I, not she, who is the focus of it and it is my thinking, not hers, that is under scrutiny." between $4^{\text {th }}$ grade and $11^{\text {th }}$ grade and had been suspended at least once every year for disciplinary infractions during that time. In the $5^{\text {th }}$ grade she was diagnosed with ADHD and given an Individualized Educational Plan though she suspected her labeling was due to teachers not being able to control her rather than to any disability, "I wasn't different from any other student. My grades were different, but my ability wasn't."

In the last two years, however, at the transfer school that recognized her potential, Alysha was passing courses and accumulating credits; she was proud of her accomplishments and how far she had come. It was during this period that the principal of her school, a young Latino with deep roots in the school's community, suggested that Alysha and I begin to work together as I had previously worked with other students of color, with and without disabilities, from the same community. He thought that working with me might boost Alysha's sense of self and give sustenance to her college ambitions. After introductions and discussions, Alysha enthusiastically agreed to co-teach a class with me for my master's preservice special-education teachers that would be based on her own experiences in school as a special education student. We subsequently co-taught six classes together over the following two years. Our many conversations preparing for the classes, our debriefing sessions afterwards, and the classes themselves were all video-recorded, and I used an arts-based methodology (Barone \& Eisner, 2012; Leavy, 2017) with her to evoke, probe, 
reflect upon, and make sense of her experiences. My arts-based methods were infused with Paulo Freire's (1970) approaches to critical pedagogy. Specifically, I would make digital and video collages based on the recordings of our sessions together, and these would "represent" to Alysha, "not as a lecture but as a problem," (p. 109) what she had said and done during our discussions and the classes. Presenting Alysha her own stories in a layered (collaged) form disrupted her own linear narrative (Butler-Kisber \& Poldma, 2010) thus prompting self-reflection about how she saw herself and wanted to be seen by others. During these reflections, Alysha would comment on the collages, question the nature of representation, and occasionally ask me to modify the collages to align more with her selfimage at that moment. Alysha told me that the images "make me think more than l'm used to thinking," and "show my intelligent side." Then, towards the end of her final year at the school, unable to erase the academic record she had accumulated before arriving there, she was rejected by the colleges to which she had applied. It was at this point that she reviewed the first draft of the article I had written about our work together and asked me to withdraw her name and likenesses from it though she remained supportive of the research itself. A few weeks later the semester ended and our communication with each other faded; Alysha had now graduated from school, and she was living at home under difficult circumstances while working long hours at job that she hated. My attempts to reach her subsequently were not successful; she did not return my text messages. Over the following months, I removed all likenesses of Alysha from the images used in the article in accordance with Alysha's wishes and submitted it to a journal for publication.

I could have interpreted Alysha's choice of anonymity rather than identity as an empowering act, a refusal of the "colonizer's gaze" (hooks, 2015), an assertion of her power over how she would be seen, or not seen, by others. In that case, it could be something to celebrate. But it did not feel that way. Alysha did not explicitly tell her principal or me that the college rejections were the reason for her decision in favor of anonymity rather than identity, and indeed her reasons for withdrawing permission for identification may have been in partial response to other new life-realities since leaving school. She may also have had reasons for choosing anonymity that were not fully formed or easy to articulate. Still, the principal's perception and my own interpretation understood her withdrawal as responding to the college rejections, a surrender to the official school narratives of failure that had pursued her relentlessly through primary and secondary schools and were now reasserting themselves to deny her recent achievements. It was at this point that I had to consider whether Alysha had benefited from the research we had done together. Her aspirations had been stifled. Meanwhile, I was able to write one more article that would help further my professional career. Within that inequity, the issues of whiteness, blackness, and ethical research took center stage. 


\section{Statistics, History, and the Role of the Researcher}

The statistical record demonstrates that Alysha's path through school is not unique. Black youth still comprise a disproportionate number of those who fail to graduate from high school and college (Casselman, 2014; Ginder, Kelly-Reid, \& Mann, 2017; NCES, 2018), are mis-diagnosed with disabilities and isolated in self-contained classrooms (Annamma, Connor, \& Ferri, 2013; Fellner, Comesañas, Duperoy, \& Duperoy, 2017), are suspended, arrested, incarcerated (Merkwae, 2015; Orfield, Losen, Wald, \& Swanson, 2004), and stigmatized in various ways (Fellner et al., 2017; Harry \& Klingner, 2006; Kauffman \& Badar, 2013) so that the fault for academic failure is seen as an individual one belonging to them alone. The evidence of black overrepresentation in all the categories listed above testifies to the continued legacy of anti-blackness that began with the Middle Passage and slavery (Sharpe, 2016) and was extended, after the Civil War, by means of Black Codes, chain gangs, prisons, forced contractual labor (Alexander, 2010; Davis, 2003; Hartman, 1997), housing projects, and ghettos (Rothstein, 2017). For Alysha, this legacy of denied and camouflaged racism manifested itself both in rote teaching that is more common among the poor than the privileged (Anyon, 1981; Orfield \& Lee, 2005), suspensions, expulsions, and in being placed by herself in the back of the room year after year where, "I sat by myself forever. I just got used to it."

With Alysha's rejection of the images she had once affirmed, the historical legacy of skin hegemony cast its shadow over our entire endeavor, and I felt even whiter than I had been before. I was forced to question if the exploration Alysha and I had engaged in together had indeed served both of us as is required by the principles of research authenticity (Guba \& Lincoln, 1989; Tobin, 2006), or if I was merely continuing the exploitative narrative of pain and sympathy that so often accompanies white narratives of black academic failure. Was I guilty of Christina Sharpe's criticism of those who "purport to make manifest 'humanity' that we already know to be present" (2016, p. 115), and feeling righteous for declaring the injustice of it all as if that injustice had not been documented ad infinitum since the first ship of human beings designated as things by people who call themselves white (Coates, 2015) arrived on the American shore? I was certainly not the first researcher to face this dilemma (see for example, Patton \& Bondi, 2015; Pennington \& Prater, 2016).

Given my failure to contact Alysha, I could not be certain of how she assessed the worth of the research we had done together despite my own sense that she had benefitted from it in significant though unmeasurable ways. I, furthermore, did not feel comfortable taking an imaginative leap to explore her feelings based on empathic desire given the difficulties of abandoning my own embodied sense of her position (Delpit, 1988) coupled with white empathy's uneasy place in the history of blackness (see Hartman, 1997). These 
thoughts relentlessly troubled me, and I continued to feel uneasy about submitting an article that had Alysha as its central focus given her reluctance to be identified with it. Finally, attending to that unease, I withdrew my previously submitted article from consideration. I nevertheless felt it important to probe my own conflicted feelings through my own unsettled gaze. Though Alysha remains an important figure in this article, it is I, not she, who is the focus of it and it is my thinking, not hers, that is under scrutiny.

Though self-examination always runs the risk of being self-indulgent, my purpose was not to center whiteness but to problematize it. Nor was it my purpose to either induce guilt or be self-exculpatory. Rather I needed to explore my own discomfort, to search for that alignment of belief and practice that now escaped me. Just as I had used arts-based methods with Alysha for purposes of evoking and reflecting upon her situation, I now used those methods to contemplate my own situation.

\section{Unfolding Experience through Arts-Based Research}

I first used arts-based research methods in my 2012 doctoral dissertation as a way of visually evoking the range of emotions and complexity of thought of severely underperforming $7^{\text {th }}$ grade African-American students. I had been a professional artist for over 20 years before returning to school for advanced degrees. It, therefore, seemed natural to me to employ artistic practices as part of my research because through art I could convey my students' passions, curiosities, and lived experiences in a way that words by themselves could not do. The artifacts produced served as provocative tools of reflection both for the students represented and for a broader community of educators. I only later became familiar with the work of Tom Barone and Eliot Eisner (2012) and the many scholarly articles devoted to arts-based research and visual methodologies. These have provided methodological analysis and critical exploration of how artistic approaches to research broaden the possibilities of qualitative research by enriching our understanding of social phenomena. They do so even as their embrace of creativity, nuance, contradictions, polysemia, emotions, ambiguity, and lack of finality and solutions often leaves unresolved and unsettled the very problems they engage. Indeed, arts-based research frequently complicates deeply embodied feelings and ideas concerning "difference, diversity, prejudice," identity, and stereotypes (Leavy, 2017, p. 13). At their most successful, the process and the products of arts-based research resonate viscerally with embodied emotions thus opening the possibility for a transformation of habitus, which, as Bourdieu and Wacquant (1992) postulated, needs to be addressed at the bodily level for transformation to occur. The purpose then of artsbased research methodologies is not to amass truths or establish generalizable findings but to evoke experiences in ways that will resonate within the deepest recesses of our shared humanity. For the artist-researcher, there is the belief that the non-literal can reach deep 
down into the recesses of our spirit where facts and figures cannot, and that it can call forth a response that will move us to better know and care for our collective and interconnected selves so that we can together fulfill our promise.

Wang et al. (2017) suggest different categories of arts-based research. One of these, Art as research, they define as a methodology in which "The act of creating is simultaneously the act of researching," a "meaning-making processes," to make "sense of the world" (p. 15). In my process, detailed below, I "attend" to "my own experience" (Kwah \& Fellner, forthcoming) as a researcher through the production of art. There are phenomenological and hermeneutic questions at the core of my project, an attempt to understand what is going on and why it is going on through artistic methods. Facilitated by the use of collage (Butler-Kisber \& Poldma, 2010), multiple meanings and voices that surround my research experience are evoked.

This particular study is also auto-ethnographic; I am trying to evoke, "my personal experience (auto) in order to understand cultural experience (ethno)" (Ellis, Adams, \& Bochner, 2011, para 1). I start from the inside, trying to "make visible the complexity and contradictions in the feelings that ... arise" within me (Kwah, Forthcoming). I notice feelings as they address me. They call forth colors, light, forms and images. My hope is that intuitively following the movement of my own visual productions will contribute to selfawareness, an important step towards group transformation (Steele, 2002). In this way I hope to catalyze movement from the micro to the macro, "relative terms in both time and space" (Collins, 1981, p. 987) that are dialectically inter-connected so that movement on any place in the scale transforms every position on it. For me, there is also a self-healing quality to arts-based methodologies (Restler, 2017), a care for the materials employed, and a joy in their use that vitalizes the spirit. There is exhilaration in the activity of art-making and a compassion for self that co-exists with feelings of despair, curiosity, reflexivity, and confusion.

\section{Arts-Based Methods Turned on Myself}

\section{The Pastels}

I had used arts-based methods to re-present to Alysha her own views on selfrepresentation in order to catalyze reflection, dialog, and self-affirmation. I now turned to art to facilitate a more personal and inward reflection, a meditation on the authenticity of the research conducted by me, and, implicitly, many other white academics in schools that serve primarily low-income students of color. I first chose to use pastels in my searching because, held between my fingers and thumb, they have always felt like an extension of my body and 
its movements, tools that effortlessly allow expression to flow through me. At its best, time seems to lose duration while I am drawing; reflection and pre-determination are thus suspended. I become the drawing; my bodily movements and the marks I make are engraved within it, the drawing and I are one. As the painter Cy Twombly wrote about the act of painting, "It's more like I'm having an experience than making a picture" (Kennedy, 2011, para 1). Determining truths and proofs are not the objective here. Nor is aestheticization. It is the resonance with experience that I seek not any preciousness or beauty. Color, tone, and form contingently and intuitively become part of the evocation. This way of researching rejects predetermination, the planning dictated by bullet points, outlines, and graphic organizers.

The historian William Sewell, Jr. (2005) defines an event as an occurrence that significantly changes the course of history. I began my exploration by re-experiencing, through drawing, a salient event from a debriefing session with Alysha that had imprinted itself on my mind and continues to trouble and excite me. Alysha had been considering some of the collages I had made when she suddenly turned to me and said:

You know, I like art too. Frida Kahlo's my favorite artist. You know her painting "Without hope?" [Figure 1]. That's an amazing painting. She's lying in bed with some type of structure over her and then there's this demon or something, a spirit coming out of her mouth. That's an amazing painting.

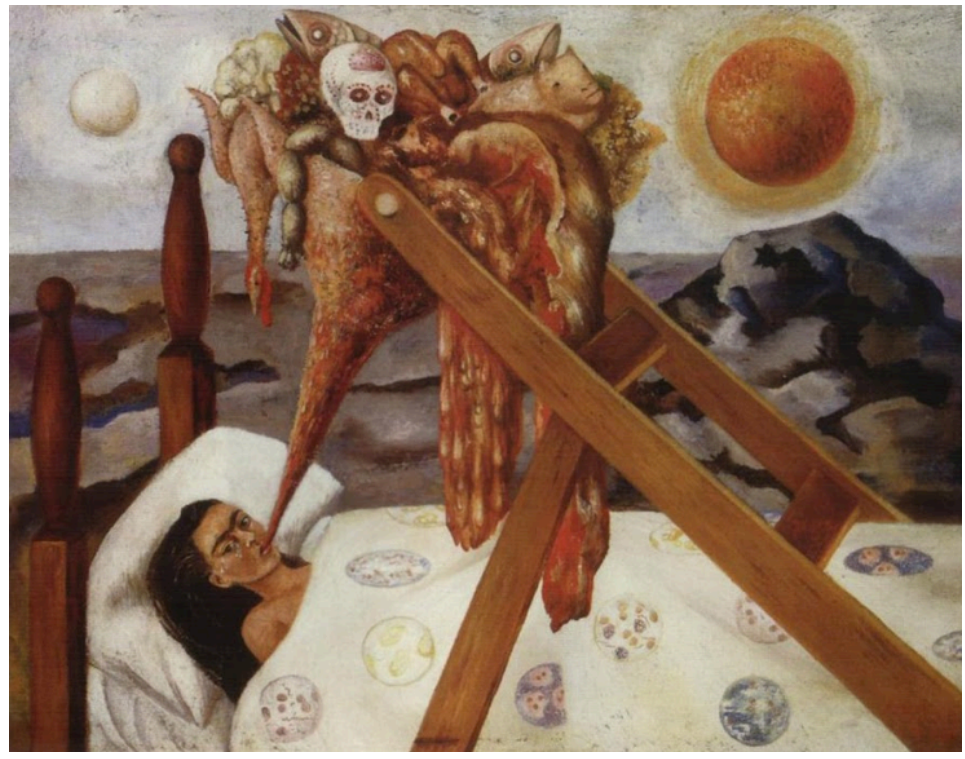

Figure 1. Frida Kahlo, Without Hope, 1945 (c) 2019 Banco de México Diego Rivera Frida Kahlo Museums Trust, Mexico, D.F. / Artists Rights Society (ARS), New York (re-printed with permission) 
In Kahlo's painting, Frida, rigid in her bed, is in tears as the "demon" either emerges from within her immobilized body (Alysha's perspective) or is being funneled into it (my perspective). The situation truly seems hopeless. What is astounding, however, is that Alysha, as she talked about Frida's hopelessness, was radiant with hope. She was staring upward at the vision of Frida's demon with an expression of ecstasy on her face, her hands cupped on either side of her head, bathed in the wonder of what Frida was able to imagine as if she was being blessed. However horrifying the demon was for Kahlo, for Alysha it was a demon full of promise. That expression of awe that had filled and illuminated Alysha captured for me her exhilarating possibilities that had thus far been denied her and that she now thought inaccessible. I sought to re-search, through drawing, my own position within that event.

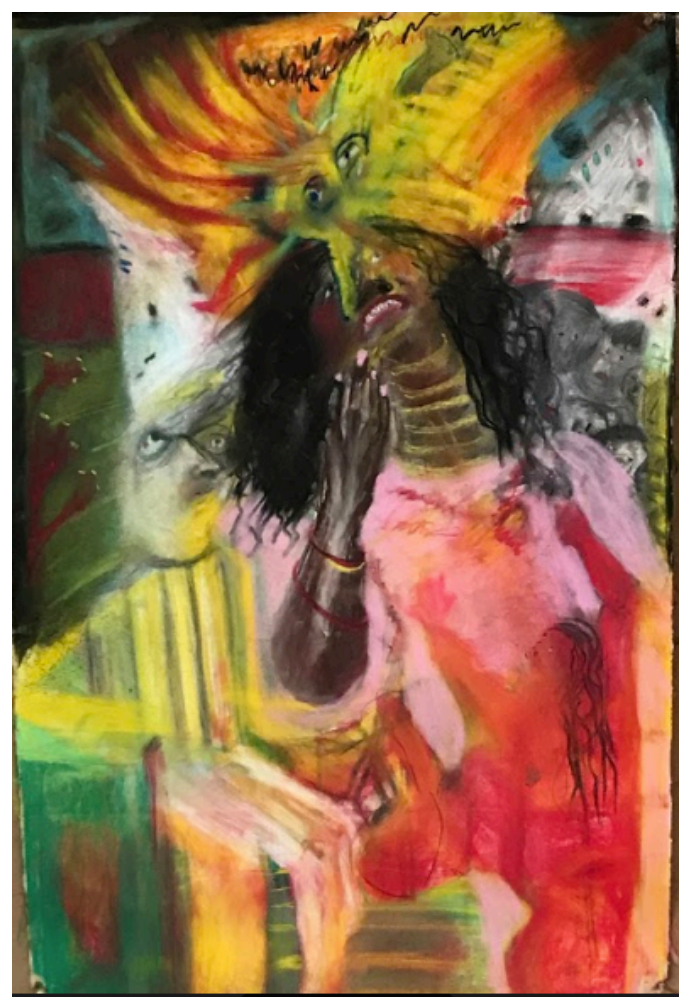

Figure 2. The demon of hope

I worked quickly, guided by intuition, making marks in rapid succession. As Alysha's face (purposefully not a likeness) materialized on the paper, the nagging discomfort about my own role as a researcher revisited me. I found myself entering the image pursued by hooded terrors that sought to attach themselves to me. I did not want them there, but I could not deny them (see Figure 2). I knew I was not the Ku Klux Klan, my acts were not commensurate with theirs, and yet I could not shed the glue of whiteness that without choice or desire bound us together. My body pictured these connections before I consciously thought them, and I cringed as I observed the forms only after I had enjoyed making them. 
Soon, multiple black faces appeared. I recognized them as the generalized faces of so many black youth dismissed as failures by an educational system before they even begin to attend school. I thought of 13-year-old Justin whose father had been killed in a police chase. He said to me, "They think I'm not going to go to college; l'll show them." Nine years later, having been in and out of jail, he is still without a high school diploma. I thought of 12year-old Tania who had "the blues, like my grandma's favorite shirt." One teacher told me, Tania "had too much attitude" and "only has herself to blame for failing." I thought of Ashley who stuck her middle finger out at me and yelled, "You think I can't read. They all think I can't read." Though the math teacher told me Ashley was a "troublemaker who should be in a special school," Ashley and I began writing poetry together and reading stories by Edgar Allan Poe. One day I returned to her school and she was gone, transferred out for reasons I was never able to discover. These students who surged into my pastel did not know much or anything about the chain gangs, Black Codes, or redlining; and most never heard of Nat Turner, W. E.B. Dubois, James Baldwin, Toni Morrison, bell hooks, or Ta-Nehisi Coates, but they experienced having their intelligence demeaned and their curiosity stifled, and they know what it means to be suspended from school and being harassed by the police. Those events shape their possibilities and their sense of possibility. James Baldwin (1963, p. 7) understood these experiences well. He wrote to his nephew, "You were born into a society which spelled out with brutal clarity, and in as many ways as possible, that you were a worthless human being. You were not expected to aspire to excellence."

The red figure in the pastel who dances wildly in front of Alysha was once a vase of flowers that the drawing rejected before morphing into a devil-disciple that belonged. Reflecting on her significance only after she refused to leave the drawing, I defined her as a jumble of all the contradictions that Alysha and her friends within the pastel carry in their bodies. She is angry and joyful, menacing and endearing, aware and ignorant, brilliant and failing, strong and vulnerable, proud and self-stigmatized. She embodies Alysha's ecstasy and misery, and she mocks the rebellion and complicity that is my coat in my profession. Alysha's yellow neckbands and red armbands came later; they are decorative and beautiful but remind of shackles, the past in the present, the chains imposed upon Alysha and the chains she has internalized. The drawing itself permits this analysis, which only occurs now as I write this text. It is an analysis shaped by my gaze, my beliefs, and my experiences. 


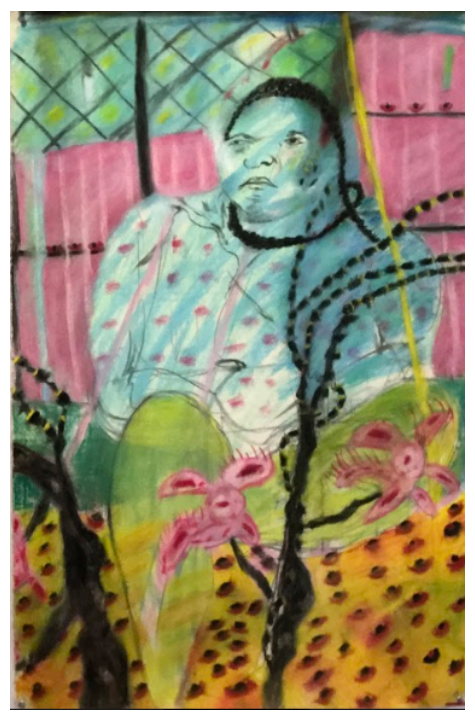

Figure 3. Untitled

I had spent about 20 hours over a period of three weeks working on the demon of hope (figure 2). Much of that time I spent waiting between periods of fervent mark-making for the pastel to tell me what it needed to resolve itself. Now that it seemed complete, however, I felt it inadequately conveyed Alysha's strength. I sought to remedy that failing in my second pastel (Figure 3). Alysha's gaze in this portrait is proudly direct, one that brooks no foolishness and, in its guardedness, remains suspicious of others. Alysha's hair, which was often wildly beautiful, conveys power and vulnerability. Alive and threatening, as if it could strangle her, it began to twist around her, finding root in both scalp and ground. The window grate, mimicking the grate in the office where we often conversed, establishes that Alysha is not in a free space; I feel the danger surrounding her but also emerging from within much as Frida's demon can be seen as both force-fed into her and spewing out from within her body. Alysha once told me, almost shouting, that she felt "in a cage, THAT'S WHAT IT WAS!" when they had put partitions around her in her old school to keep her from talking to others. Her words came back to me now, provoked by my drawing.

A week after finishing the second pastel (Figure 3), however, it disappointed. Though purposefully not identifiable as Alysha, the portrait was an effort to represent her through my eyes at a time when I doubted my right to represent her at all. The act of drawing her body and her situation, of trying to feel what she felt, was an act that I needed to regard cautiously. Instead of channeling her through me, I needed to insert myself back into the image as the subject of my own artistic scrutiny. What I was grappling with had to do not with Alysha per se but with my relationship to her and with others like her; I was struggling with the "we" not with the "she or "they." I began to play digitally, over and over again, with the images from the pastels, producing multiple collage iterations that I hoped would help me to "emerge from submersion" (Freire, 1970, p. 109). 


\section{The Digital Collages}

First collage. The collage form is inherently adept at illuminating complex situations, the many-leveled planes on which we are constantly engaged. It evokes multiple voices and meanings through the simultaneous presentation of "co-existing and contesting images and ideas" that overlap, abut, and merge with each other providing "the perspectival multiplicity that is necessary for critical engagement" (Garoian, 2006, p. 48). Though the images may not seem to dialog with one another obviously and can be jarring in their encounters, their arrangement can reveal "unconscious connections and new understandings" as we perceive them in relationship to each other (Butler-Kisber \& Poldma, 2010). Such seeing that is inherently infused with contradiction and yet is part of a whole facilitates the disruption of the hegemonic gaze, thus making possible a "countervisuality" (Mirzoeff, 2011), a new way of seeing that contests the taken-for-granted. The process of working with digitized images does not access the same embodied movements that drawing with pastels does. In some ways the artist seems less invoked by the artifact - her marks and movements less vital. Still, the frenetic pace at which I sometimes worked, producing scores of digital images every hour, and the use of images I had either drawn myself or were dear to me, sustained an emotional exhilaration in the doing that seemed to maintain identity between me and image while I was working.

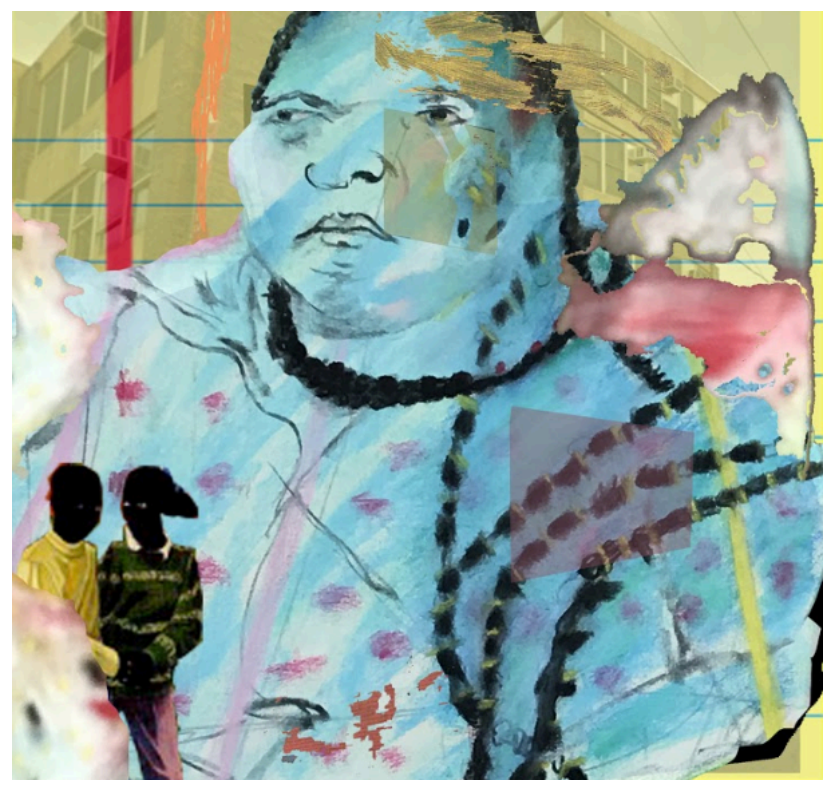

Figure 4. Untitled

In collage Figure 4, the digitized image of Alysha taken from my second pastel (Figure 3 ) is joined with images of hooded white figures from my first pastel (Figure 2). The collage 
also includes a manipulated image of Alysha's old school (downloaded from the internet) that had been, in unmanipulated form, part of one of the collages Alysha and I had discussed. When Alysha recognized the school she reflected, "I'm glad that school is behind me. It's in the past." At the time her comment conveyed optimism and expectations of great possibilities. Now, many months later as I reflected on this new collage, the school did not seem to be in the past anymore. Despite my caution about seeking empathy, the lined paper that I associated with school drudgery (and were also included in collages Alysha had seen) now came to symbolize for me the drudgery that Alysha associated with school. Assorted marks that I created in-the-moment, and smears of color taken from a painting by the artist, Cy Twombly, that happened to be sitting on my desk, also found their way into the collage. Also entering were two African-American youths holding hands from Kerry James Marshall's 1994 painting Better homes, better gardens, a painting that evokes for me the destroyed dreams of so many of the young people with whom I work. These youths had been in one of the layered images I had shown Alysha; she had looked at them and said, "Oh, you gave me friends," a poignant remark given that she had previously spoken about being placed, alone by herself, at the back of the classroom year after year.

My process in making, appropriating and joining images in this collage (Figure 4) was again intuitive; I did not begin with a list of images to use nor did I follow a logical formula for selecting or rejecting them. The Cy Twombly postcard just happened to be "at hand" (Schutz, 1967) and worked for me on a the level of feeling. Twombly's marks complicated Alysha's expression and the wounds inflicted on her. In the collage, the meaning of all these images, previously unknown to each other, emerge in their proximity to create their own visual-narrative as they converse with each other and the viewer. I was not sure if the white images, appropriated from the first pastel and evoking terror represented me or not, but I had intended to enter the collage in my role as a white researcher, and these were the only white figures that were there. Still, when I was done and separated myself from the image, a process necessary for reflexivity to take place, I realized that the desire for placing myself in Alysha's shoes still tugged at me. Though that desire had many positive and situated possibilities, it was not where I needed to go.

More collages. To further investigate the unsettled relationship between Alysha and me and, by extension, that of students of color and researchers, I had to be explicitly present in the collages as I had been in the first pastel. Though the decision to do so was purposeful, the speed with which I worked precluded careful deliberation and fostered spontaneity, what Leavy (2017, p. 11) describes as, "trial and error, changing course based on new ideas and insights and relying on one's internal monitor or hunches." In Figure 5, my self-portrait from figure 2 is layered with a darkened version of Alysha from figure 3 along with the image of her school, Marshall's youths, and multiple drawn iterations of those youths that I drew and 
then digitized. There is also a white spook on the bottom, sneaking in his gaze. I appear in the image, large but incomplete and uncertain. Am I a witness like the spook? Am I also a perpetrator? The red line behind me, bloody, is both a literal and metaphoric margin. Distorted black faces merge with Alysha and form both sky and protagonist. They challenge the viewer directly. Are the viewers complicit as well?

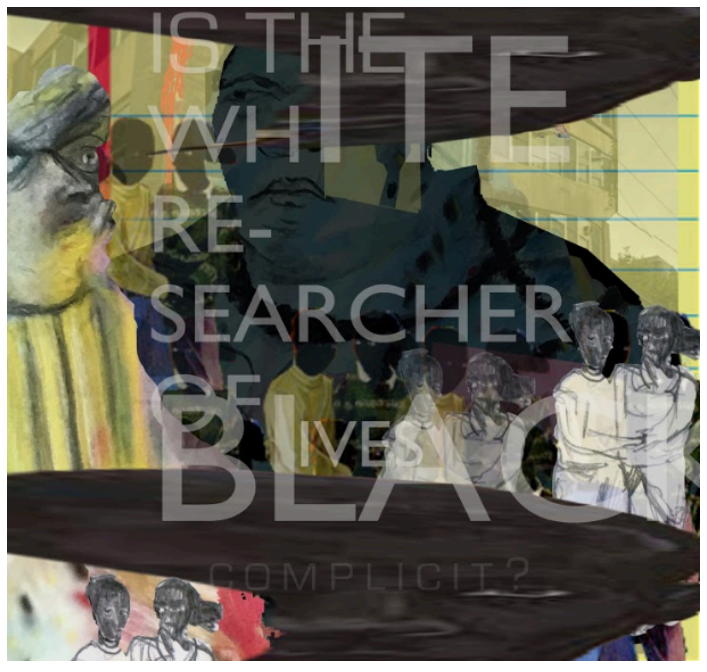

Figure 5. Untitled

I then began to focus more exclusively on myself, gradually removing Alysha and other students from the picture. In figure 6 (below) I have repeated self-portraits (from Figure 1) overlaying slave ships. Towards the bottom of the image lurks the gaze of Robert E. Lee. Both the images of the ships and of Lee are ones that I directly associate with slavery, dehumanization, and the privilege of whiteness sewn into America's continuing history. At some point, spontaneously, I added a Jewish star to one of the self-portraits (upper right). Initially, I was not sure why I needed or wanted to do that. Later, I recognized it as an attempt to distance myself from whiteness and from a history that binds whiteness to privilege and systemic terror. The star recognized my own family's flight from the Nazi's; my grandparents' internment in camps where three of them were killed because they were not seen as white (though my white skin is theirs); the ship on which my father's parents went from unwelcome port to unwelcome port finally shipwrecking off the coast of Rhodes; and my own intensifying sense of non-whiteness, of estrangement, as a result of the policies and rhetoric coming out of Washington. My striped shirt, maybe unconsciously mimicking concentration camp uniforms, may have also served to distance myself from white terror. Though I have always been a dissident, I am taken aback by my sudden zeal to shed my white identity. I consider Pennington's and Prater's (2016, p. 127) objection that we should not distinguish good whites from bad whites since "all whites ... receive social advantages because of this positionality." Still, on the level of "feeling" rather than that of a political logic and correctness, that is exactly what I needed to do. Despite benefiting from whiteness, 
despite my inability to detach myself from the color lines upon which American society was built, I did not want to be measured solely by the color of my skin. I wanted my individual actions and history to matter. This is, I believe, a human desire not a racial one, though complicity cannot be erased through desire alone. That the star, simultaneously, can be interpreted as illuminating the role of some Jews in perpetuating the slave trade is a testament to how complex and contradictory all our histories are and how the viewer's gaze, an equal collaborator of interpretation, is central to arts-based meaning-making.

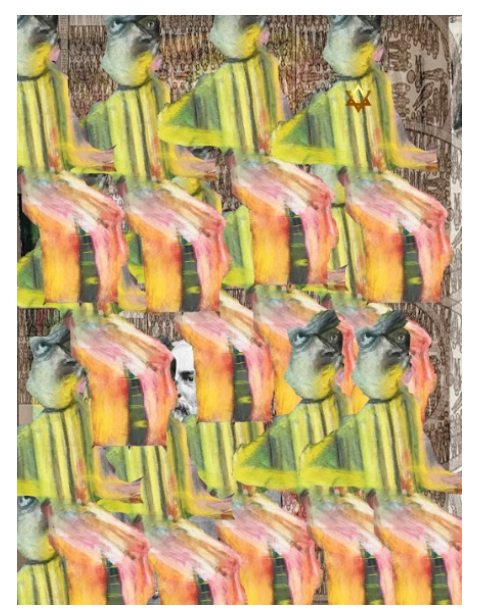

Figure 6. Untitled

The Researcher's Dilemma

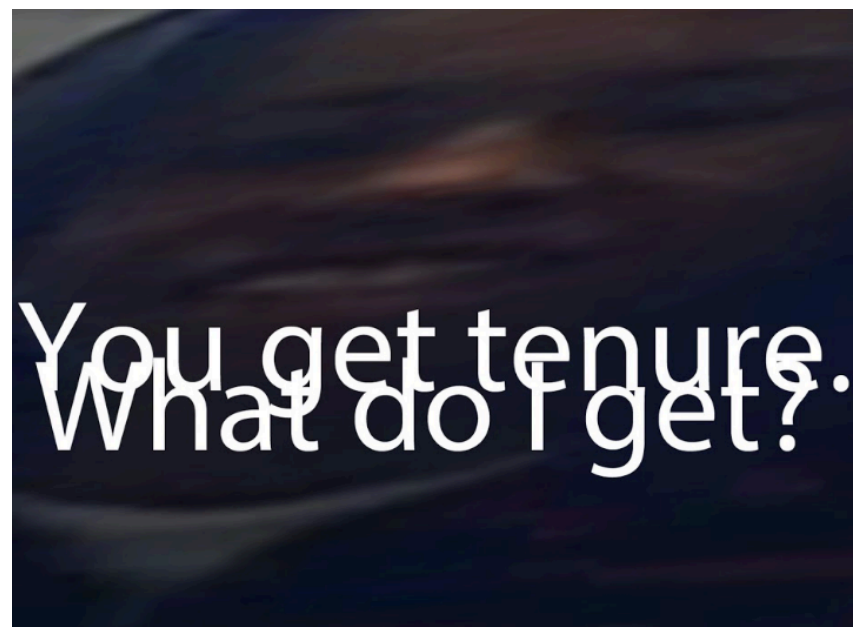

Figure 7. Untitled

In the 1970s, fresh out of college, I joined the staff of the Attica Brothers Legal Defense, the organization run by and defending the 61 men charged with leading the Attica Prison Uprising of Sept. 9-13, 1971. In figure 8, An image of the Attica Uprising merges with my portrait of Alysha and Marshall's youths because I felt, even before reading Sharpe's In 
the wake: On blackness and being (2016), that Alysha's situation and Attica were part of the same 400-year long event that began with the Middle Passage. I remember the Attica days

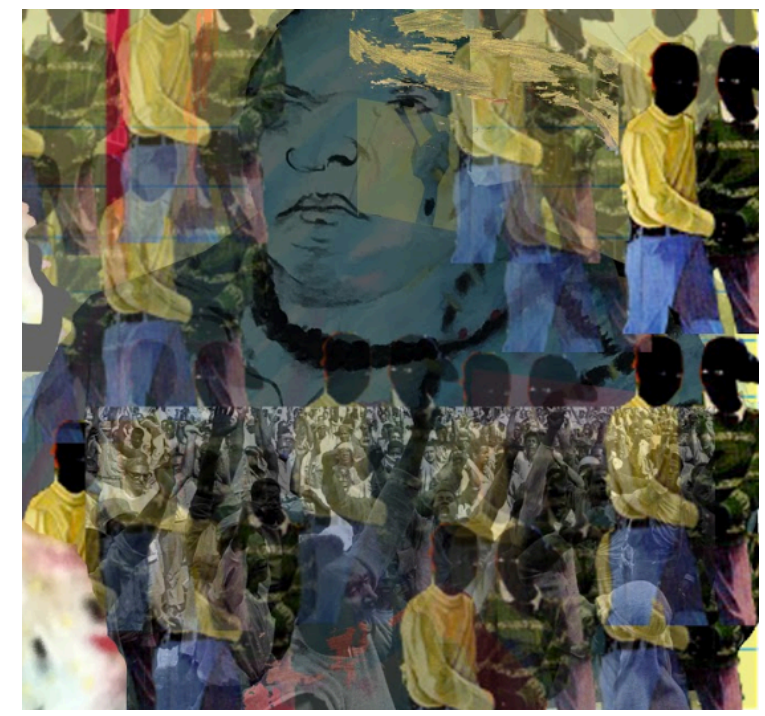

Figure 8. Alysha and Attica, part of a 400-year-long event

for the dangerous, unfocused anger that I harbored within me but also for the exhilarating feeling that whites and blacks working together could make a revolution that would create a better world; we had no doubts then that our actions mattered and that we could intervene in reality to rid the world of injustice. I was not a lawyer, but I wrote or edited many of the organization's leaflets, brochures, and press releases, helped raise money, and spoke on college campuses about the cases while also building local community support around them. Additionally, many times a week, I would go into the jails and prisons to discuss political and legal strategy with the Brothers who were incarcerated and who, along with their fellow defendants "on the streets," directed the Defense. The most revolutionary of the Brothers would tell me, repeatedly, that there were not many true white allies of black people, not too many "John Browns." Certainly, in their minds, there were good whites and bad whites. I became intrigued with John Brown (seen with his family in my digitally modified pastel, Figure 9), the white man with the long beard who, I discovered, was a close friend of Frederick Douglass and Harriet Tubman, and I began to research his life. In 1859, Brown, against the advice of Douglass, seized the arsenal in Harper's Ferry Virginia with a band of both black and white men in an effort to arm people who had been enslaved. He was captured by Robert $\mathrm{E}$. Lee in an attack that killed two of his sons along with eight other members of his party. Subsequently, Brown was hanged along with six other raid participants. In 1909, W. E. B. Du Bois wrote a deeply profound and beautiful book about this rare white man who gave his life to end slavery. During my Attica days, I studied and pondered Brown's story and once even participated in an action that risked serious violence 
but luckily avoided it. Though I immediately regretted my participation in that action, I later understood it as a youthful effort to prove my mettle, to establish that I could be a trusted white ally of the oppressed, a John Brown.

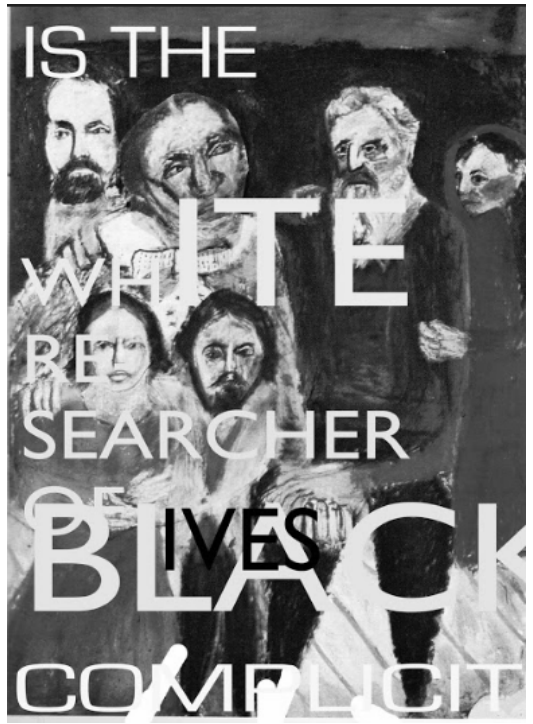

Figure 9. John Brown, his wife Mary, his sons Oliver and Watson Brown who were killed at Harper's Ferry, his daughter Anne, and Watson Brown's wife, Isabelle.

It is not unusual to think that commitment to a righteous cause must sometimes involve the commission of violent acts, but I did not feel revolutionary afterwards; on the contrary, I felt diminished in ways that might be similar to how some of Brown's sons felt after the earlier battles in Kansas when they recoiled at the terror they themselves had committed serving the anti-slavery cause. Even knowing that the violence they enacted was far less than that committed by those who maintained the slave system, they still felt their own humanity was damaged by committing violence against fellow beings, even ones who had committed reprehensible acts and had actively sustained a system based on terrorizing the black population.

Absolute refusal, then, enacts a stiff price, and we cannot all be, or want to be, John Browns. Indeed, for our system to be transformed, we need as well our Emersons, Thoreaus and Whitmans, who all praised Brown's act but did not engage in similar ones, and the abolitionists, known as the "radicals," who relentlessly pressed the uncommitted Lincoln to end slavery even as they unavoidably profited from a system built upon it (Foner, 2010).

It is also true that neither John Brown's raid nor the far greater violence of the Civil War, in which an estimated 750,000 people were killed (Hacker, 2011), were sufficient to dissolve the racist marrow of the American system. True, formal slavery ended, but in the 
wake of the Civil War, when it was vividly apparent that the wealth of the United States had been built on the backs of those who had been enslaved, the central problem of humanization (Freire, 1970) and its axiological place in the minds and bodies of most white people remained viciously unresolved. Overt and hegemonic violence against black bodies thus continued and continues as a core component around which American capitalism revolves. As central to that enterprise, the hegemonic association of success with the power to treat human beings as things that can be brutalized and monetized was maintained. I write this not to diminish the crucial imperative to fight racism specifically but to acknowledge the foundational capitalistic values of power and materialism which are not racially specific. Still, neither race nor capitalism are "ontological givens" (Ahmed, 2007, p. 150). It remains our task to disempower whiteness as a fount and conduit of privilege just as it was the task of the unnamed blacks and whites who served on the underground railroad, marched in Selma, and supported the Black Panthers even as, in other ways, they were complicit with a system permeated by racism merely because they chose to live rather than to die. We are stuck, uncomfortably, in the muck of contradiction, railing against a system we are in some ways abetting, paying taxes to support policies and structures we abhor, and working in schools and universities in which race and possibility are insidiously intertwined even as we advocate for reparations, demonstrate, and publicly condemn racist policies and practices. This is not a rationale for acceptance. There is still a gap between denouncing racial privilege and examining one's own comfort that needs to be explored and acted upon.

The images I created as part of this project were an effort to explore that gap, to access my own discomfort with my privilege as a white researcher working in communities of color. The near certainty that I would benefit professionally from my research joined with my doubts that Alysha would also reap benefits from it created an imbalance that troubled me. That disquiet lodged within me despite my understanding that Alysha's failure to be accepted into college did not rest solely within her or me but was etched into a system designed to fail black youth.

Through arts-based methods that relied on sensing rather than analysis, I could understand my inner conflict newly, re-orient my attention and try to make sense of how I felt. The process joined self-care for my spirit (Restler, 2017), which is embraced by the very joy of art-making, with subjection to my own critical gaze. The images did not seek to lecture me or to incite shame or guilt. Rather, they sought to problematize my own identity as an educational researcher. As I drew and collaged, forms emerged before conscious awareness could cast its critical gaze. Later, separating myself from my drawing, I discovered that the terror that whiteness sanctions continually slipped onto my image, establishing complicity despite my efforts to escape it. My own historical experience as a member of a terrorized group did not abdicate my responsibility to recognize my current identification as white and 
privileged though it did make that identity more nuanced and unstable. It also might have facilitated my deeply felt and persistent attempts to empathize for Alysha's situation even as I knew that I could never arrive at true empathy. Still, my attempts to feel Alysha's situation were embodied in the very act of creating art in which Alysha was so centrally present even when her image was absent. Those attempts give me hope. They are a recognition that my own possibilities of being fully comfortable in my own skin are inaccessible as long as the meaning of skin continues to signify power and privilege; in that way the struggle for humanization is not a question of merely helping others or being an ally, but of personal survival, as well. I also, however, regard my attempts at empathy with caution. Its transformative power to dismantle racial privilege is challenged by the very existence of this article that may help further my career as a white researcher while doing nothing to further Alysha's. In that way, ironically, it risks enhancing rather than diminishing the very skin privilege I seek to confront.

Research authenticity requires that all participants in the research endeavor benefit from the research activity (Guba \& Lincoln, 1989; Tobin, 2006). The urgency of that demand calls us to attention. It is made palpable by the unlimited and yet unfulfilled promise that radiated from Alysha's expression of hope-filled ecstasy, still imprinted in my mind, as she described Kahlo's “demon" in the painting, Without Hope. Though Alysha, marked by 400 years of anti-blackness, may think the fault for her unmet aspirations lies only within herself, the truth is that the fault belongs to all of us, including markedly those who profit from her continued disempowerment. I hope this article will evoke my own attempts to grapple with my own place on that fault line and with my own struggle to make my research matter, materially, to those I claim to serve. 


\section{REFERENCES}

Ahmed, S. (2007). A phenomenology of whiteness. Feminist Theory, 8(2), 149-168. https:// doi.org/10.1177/1464700107078139

Alexander, M. (2010). The new Jim Crow. New York, NY: The New Press.

Annamma, S. A., Connor, D., \& Ferri, B. (2013). Dis/ability critical race studies (DisCrit): Theorizing at the instersctions of race and dis/ability. Race Ethnicity and Education, 16(1), 1-31. https://doi.org/10.1080/13613324.2012.730511

Anyon, J. (1981). Social class and school knowledge. Curriculum Inquiry, 11(1), 3-42.

Baldwin, J. (1963). The fire next time. New York, NY: Vintage Books, Random House.

Barone, T., \& Eisner, E. W. (2012). Arts based research. Los Angeles, CA: SAGE Publications.

Bourdieu, P., \& Wacquant, L. J. D. (1992). An invitation to reflexive sociology. Chicago, IL: University of Chicago Press.

Butler-Kisber, L., \& Poldma, T. (2010). The power of visual approaches in qualitative inquiry: The use of collage making and concept mapping in experiential research. Journal of Research Practice, 6(2), M13.

Casselman, B. (2014). Race gap narrows in college enrollment, but not in graduation. FiveThirtyEight. Retrieved from https://fivethirtyeight.com/features/race-gap-narrowsin-college-enrollment-but-not-in-graduation/

Coates, T. N. (2015). Between the world and me. New York, NY: Spiegel \& Grau.

Collins, R. (1981). On the microfoundations of macrosociology. American Journal of Sociology, 86, 984-1014. https://doi.org/10.1086/227351

Davis, A. Y. (2003). Are prisons obsolete. New York, NY: Seven Stories Press.

Delpit, L. D. (1988). The silenced dialogue: Power and pedagogy in educating other people's children. Harvard Educational Review, 58(3), 280-298. https://doi.org/ $\underline{0017-8055 / 88 / 0800-0280 \$ 01.25 / 0}$ 
Ellis, C., Adams, T. E., \& Bochner, A. P. (2011). Autoethnography: An overview. Forum: Qualitative Social Research, 12(1). Retrieved from http://nbn-resolving.de/ urn:nbn:de:0114-fqs1101108

Fellner, G., Comesañas, M., Duperoy, L., \& Duperoy, Y. (2017). What it means to be special: Two sisters discuss their experiences. Disability \& Society, 32(3), 323-343. https:// doi.org/10.1080/09687599.2017.1296817

Foner, E. (2010). The fiery trial: Abraham Lincoln and American slavery. New York, NY: W. W. Norton \& Company.

Freire, P. (1970). Pedagogy of the oppressed. New York, NY: Continuum.

Garoian, C. R. (2006). Silent gaps of visual culture. Visual Arts Research, 32(2), 48-55.

Ginder, S. A., Kelly-Reid, J. E., \& Mann, F. B. (2017). Graduation rates for selected cohorts, 2007-12; student financial aid, academic year 2014-15; and admissions in postsecondary institutions, fall 2015 (No. NCES 2017-084). Washington, D.C.: National Center for Education Statistics.

Guba, E. G., \& Lincoln, Y. S. (1989). Fourth generation evaluation. Thousand Oaks, CA: SAGE Publications.

Hacker, J. D. (2011). A census-based count of the Civil War dead. Civil War History, 57(4), 307-348. https://doi.org/10.1353/cwh.2011.0061

Harry, B., \& Klingner, J. (2006). Minority students in special education? Understanding race \& disability in schools. New York, NY: Teachers College Press.

Hartman, S. V. (1997). Scenes of subjection. New York, NY: Oxford University Press.

hooks, bell. (2015). Black looks: Race and representation. New York, NY: Routledge.

Kauffman, J. M., \& Badar, J. (2013). How we might make special education for students with emotional or behavioral disorders less stigmatizing. Behavioral Disorders, 39(1), 1627. 
Kennedy, R. (2011, 5). Cy Twombly, Idiosyncratic painter, dies at 83. New York Times. Retrieved from http://artsbeat.blogs.nytimes.com/2011/07/05/cy-twomblyidiosyncratic-painter-dies-at-83/?scp=2\&sq=cy\%20twombly\&st=cse

Kwah, H. (2018). Buddhist and arts-based practices for addressing racial oppression: Building upon Cleveland and Tobin's mindfulness in education. Cultural Studies of Science Education. https://doi.org/10.1007/s11422-018-9898-5

Kwah, H., \& Fellner, G. (forthcoming). Contemplative, visual arts-based research methods for self-care and transformation. In K. Alexakos \& K. Tobin (Eds.), Methodologies for multilevel research in teacher education. The Netherlands: Brill-Sense Publishing.

Leavy, P. (2017). Introduction to arts-based research. In P. Leavy (Ed.), Handbook of artsbased research (pp. 3-20). New York, NY: Guilford Publications.

Merkwae, A. (2015). Schooling the police: Race, disability, and the conduct of school resource officers. Michigan Journal of Race and Law, 21(1), 147-181.

Mirzoeff, N. (2011). The right to look. Critical Inquiry, 37(3), 473-496.

NCES. (2018). State high school graduation rates by race, ethnicity. Washington, D.C.: National Center for Education Statistics. Retrieved from http://www.governing.com/ gov-data/education-data/state-high-school-graduation-rates-by-race-ethnicity.html

Orfield, G., \& Lee, C. (2005, January 13). Why segregation matters: Poverty and educational inequality - The Civil Rights Project at UCLA. Retrieved September 1, 2013, from http://civilrightsproject.ucla.edu/research/k-12-education/integration-and-diversity/ why-segregation-matters-poverty-and-educational-inequality

Orfield, G., Losen, D., Wald, J., \& Swanson, C. B. (2004). Losing our future: How minority youth are being left behind by the graduation rate crisis. Harvard University. Retrieved from http://www.civilrightsproject.harvard.edu

Patton, L. D., \& Bondi, S. (2015). Nice white men or social justice allies?: Using critical race theory to examine how white male faculty and administrators engage in ally work. Race Ethnicity and Education, 18(4), 488-514. https://doi.org/ $\underline{10.1080 / 13613324.2014 .1000289}$ 
Pennington, J. L., \& Prater, K. (2016). The veil of professionalism: An autoethnographic critique of white positional identities in the figured worlds of white research performance. Race Ethnicity and Education, 19(5), 901-926. https://doi.org/ $\underline{10.1080 / 13613324.2014 .885431}$

Restler, V. (2017). Re-visualizing care: Teachers' invisible labor in neoliberal times (Doctoral dissertation). City University of New York, New York.

Rothstein, R. (2017). The color of law: A forgotten history of how our government segregated America. New York, NY: W. W. Norton \& Company.

Schutz, A. (1967). The phenomenology of the social world. (G. Walsh \& F. Lehnert, Trans.). Chicago, IL: Northwestern University Press.

Sewell Jr., W. H. (2005). Logics of history. Chicago, IL: The University of Chicago Press.

Sharpe, C. (2016). In the wake: On blackness and being. Durham, NC: Duke University Press.

Steele, S. (2002). The age of white guilt and the disappearance of the black individual. Harper's Magazine.

Tobin, K. (2006). Qualitative research in classrooms: Pushing the boundaries of theory and methodology. In K. Tobin \& J. Kincehloe (Eds.), Doing Educational Research (pp. 1557). Rotterdam, The Netherlands: Sense Publishers.

Wang, Q., Coemans, S., Siegesmund, R., \& Hannes, K. (2017). Arts-based methods in socially engaged research practice: A classification framework. Art | Resarch International, 2(2), 4-39. 